\title{
Miranda
}

Revue pluridisciplinaire du monde anglophone /

Multidisciplinary peer-reviewed journal on the English-

speaking world

$11 \mid 2015$

Expressions of Environment in Euroamerican Culture / Antique Bodies in Nineteenth Century British

Literature and Culture

\section{Dale Townshend, Angela Wright (eds), Ann Radcliffe, Romanticism and the Gothic}

\section{Laurence Talairach-Vielmas}

\section{(2) OpenEdition \\ 1 Journals}

Electronic version

URL: https://journals.openedition.org/miranda/7149

DOI: $10.4000 /$ miranda. 7149

ISSN: 2108-6559

Publisher

Université Toulouse - Jean Jaurès

\section{Electronic reference}

Laurence Talairach-Vielmas, "Dale Townshend, Angela Wright (eds), Ann Radcliffe, Romanticism and the Gothic", Miranda [Online], 11 | 2015, Online since 22 July 2015, connection on 08 September 2022.

URL: http://journals.openedition.org/miranda/7149 ; DOI: https://doi.org/10.4000/miranda.7149

This text was automatically generated on 8 September 2022.

\section{(c)}

Creative Commons - Attribution-NonCommercial-NoDerivatives 4.0 International - CC BY-NC-ND 4.0

https://creativecommons.org/licenses/by-nc-nd/4.0/ 


\title{
Dale Townshend, Angela Wright (eds), Ann Radcliffe, Romanticism and the Gothic
}

\author{
Laurence Talairach-Vielmas
}

\section{REFERENCES}

Dale Townshend, Angela Wright (eds), Ann Radcliffe, Romanticism and the Gothic

(Cambridge: Cambridge University Press, 2014), 257 p, ISBN 978-1-107-03283-5

11764 marked both the publication of the first Gothic story, Horace Walpole's The Castle of Otranto (1764), and the birth of one of the most popular Gothic writers of the romantic period-Ann Radcliffe. 250 years later, Ann Radcliffe, Romanticism and the Gothic, edited by Dale Towshend and Angela Wright, freshly re-examines Radcliffe's work, looking at the impact and reception of her cuvre and its relationship to the Romantic literary and cultural contexts. If the Gothic was considered as low mass fiction characterized by repetitions and stereotypes and believed to be written by women for women, romanticism was associated with poetry and high art. However, as this collection of articles demonstrates, the links between the Gothic and Romanticism were much more complex: the Romantic literary culture often distorted facts of the Gothic and the Romantic aesthetics were more often than not informed by Gothic conventions and read by the main Romantic artists, as Percy Bysshe and Mary Shelley probably best illustrate. The 13 chapters are organised into 3 different parts, entitled "Cultural Contexts", "Ann Radcliffe's Creative Output" and "Ann Radcliffe and Romantic Literary Culture". In Part I, the first chapter, by Dale Towshend and Angela Wright, looks at the critical reception of Radcliffe's fiction from her first novels to her last publications. Townshend and Wright explain how Radcliffe addressed the criticisms raised in many reviews or how her first novels often met mixed critical responses. Her rendering of landscape and her poems were not particularly acclaimed, and Radcliffe's reputation ironically only rose in 1798-1823 when she vanished from 
the literary scene. As Townshend and Wright recall, in the first half of the $19^{\text {th }}$ century Radcliffe's fiction was read by the romantic poets and sometimes even emulated or parodied. The second chapter, by Joe Bray, deals with the way in which Radcliffe engaged with late $18^{\text {th }}$ century debates around the portrait. As a staple of Gothic fiction, the animated portrait has always been a means of probing the boundary between representation and reality. Radcliffe's use of the portrait, as in The Mysteries of Udolpho and The Italian, shows how the motif of the portrait helps her bring into question the nature of reality. In the following chapter, Edward Jacobs analyses Radcliffe's influence on romantic print culture as well as on later literary and print cultures. Indeed, the success of the Gothic as a genre cannot be envisaged without taking into consideration the role of the circulating libraries, which not only ensured Radcliffe's success but also that of numerous (mainly) female authors of Gothic romances. Radcliffe published her fiction anonymously until The Mysteries of Udolpho (1794); but it soon became obvious that The Castles of Athlin and Dunbayne: A Highland Story (1789), A Sicilian Romance (1790) and The Romance of the Forest (1791) were written by a woman, as suggested by the addition of "by the authoress of" on the front page of her novels, as underlined by Townshend and Wright in the first chapter. Some circulating library publishers, such as Thomas Hookham, specialised in female authors, particularly capitalised on "authoresses" to promote their publications. Or so did the Romantic age believe, Jacobs argues, as illustrated by Isabella Thorpe's reading in Jane Austen's Northanger Abbey (1818). The way in which Romantic literary culture may have exaggerated the actual proportion of female authors or of women using circulating libraries may be partly responsible for the condemnation of the Gothic as a genre likely to corrupt the tastes of the public. The part played by the Gothic in early debates about low "mass" culture, and the influence of women, as both writers and readers, lies thus at the heart of Jacobs's chapter which nonetheless explains how the Romantic literary culture may have distorted parts of the story (more men actually subscribed to circulating libraries, for instance). Chapter 4, by James Watt, closes the first part by focussing on the political resonances of some of Radcliffe's novels, her views of progress as shown by her depictions of savagery, and tries to trace a few topical terms or allusions throughout her novels.

2 In Part 2, Alison Milbank examines "ways of seeing" in The Castles of Athlin and Dunbayne and A Sicilian Romance in order to highlight how Radcliffe may have anticipated the Romantic visionary perspective. Whilst Radcliffe's writing is often organised around a series of visual images, her sources of inspiration often came from travel guides or paintings, like those of Salvador Rosa, as in A Sicilian Romance. Chapter 6, by Diane Long Hoeveler, examines The Romance of the Forest and the impact of some of the motifs, such as the ruined and haunted abbey, the manuscript or the skeleton in the chest which became clichés of the genre and were recurrently re-used, adapted or parodied. Hoeveler mentions several adaptations of the novel (such as J.J. Horsley Curties's Ancient Records; Or, the Abbey of St Oswythe (1801) and The Horrors of Oakendale Abbey (1797) by Elizabeth Carver, which both play upon the motif of the skeleton in the chest (although Hoeveler seems unaware of the real identity of "Mrs Carver" and the particularities of the giant skeleton in the latter example). The chapter emphasizes the way in which the Gothic conventions that arguably originated in Radcliffe's novel became widespread either through rewritings or even translations into French, German or Italian. In Chapter 7, Robert Miles looks at The Mysteries of Udolpho to probe the connections between the Gothic and Romanticism so as to show how Radcliffe's fiction 
was in fact pre-Romantic and far from writing low-brow fiction as many of her detractors claimed. Travel writing is tackled in the following chapter, by JoEllen DeLucia, who examines the aesthetic treatments of space and time in Radcliffe's $A$ Journey Made in the Summer of 1794... (1795) and the way in which Radcliffe "troubles the distancing and mediating techniques used to gauge Romantic writers' experience of foreign and familiar lands" (136). Radcliffe's narrative is informed by works such as Samuel Johnson's A Journey to the Western Islands of Scotland (1775) and many of her views (as argued in the preceding chapters, although no connection is made here), resemble the paintings of Salvator Rosa or Claude Lorrain. Radcliffe's accounts of the Continent, DeLucia contends, deal with the issue of national identity and undoubtedly impacted her views on Britishness and perceptions of her native country. In Chapter 9 , on The Italian; or, the Confessional of the Black Penitents (1796-97), Jerrold E. Hogle explains how Radcliffe's novel, written in reaction to Lewis's The Monk (1797), is informed by Walpolean elements, as defined in his preface to the second edition of The Castle of Otranto. As she blends the "ancient" and the "modern", Radcliffe proposes a romance that anticipates Wordsworth and Coleridge's romanticism, Hoggle contends. The following chapter, on Gaston de Blondeville (1826), Radcliffe's alleged final novel, relates how the authoress met harsher reviews, although, as Samuel Baker shows, the text, started around 1802 may have anticipated developments in the Gothic mode and Romanticism more generally.

The last part of the edited collection comprises three chapters on Ann Radcliffe's poetry (Jane Stabler), on Radcliffe's influence on Romantic fiction from the 1790s to the 1830s (Sue Chaplin) and on stage adaptations between 1794 and 1806 (Diego Saglia). The issue of literary taste and the Gothic's appropriation by Jane Austen and Walter Scott, just as Radcliffe's relation to the early $19^{\text {th }}$ century novel of manners and Scott's historical romances leads Chaplin to argue, for instance, that Radcliffe's fiction may have been on the side of "high culture", a view that counteracts to some extent earlier discussions about the reception of Radcliffe's novels and the issue of aesthetic merit. The example of Henry Tilney, in Jane Austen's Northanger Abbey is once again conjured up to highlight Tilney's ability to distinguish Radcliffe's fiction from other "horrid" romances, an ability to discriminate which typifies the young man's "taste". This exploration of the context in which Radcliffe's novels were produced and circulated, informed by many historical facts is undoubtedly a significant addition to Gothic criticism and certainly helps reconsider Radcliffe's fiction. One may regret the absence of a substantial introduction and/or the lack of links between chapters, however, especially as issues such as that of aesthetic taste and Radcliffe's influence on the emergence of mass fiction is pointed out in several articles and partly lies at the basis of the debate on the relationship between the Gothic and romanticism. But the collection nonetheless provides a fascinating insight into the impact of Radcliffe's cuvre in the Romantic period and beyond and should appeal to scholars interested in the origins of the genre and the genesis of Gothic conventions. 
INDEX

Keywords: Ann Radcliffe, the Gothic, romanticism

Mots-clés: Ann Radcliffe, roman noir, Gothique, romantisme

\section{AUTHORS}

\section{LAURENCE TALAIRACH-VIELMAS}

Professeur

Université Toulouse Jean Jaurès

talairac@univ-tlse2.fr 